\title{
Timing of Mergers and Acquisitions: Evidence from the Canadian Stock Market
}

\author{
Imen Tebourbi \\ Correspondence: Imen Tebourbi, Hamline University, School of Business, MS-A1745, 1536 Hewitt Avenue, \\ Saint Paul, MN 55104-1284, USA. Tel: 1-651-523-2102. E-mail: itebourbi01@hamline.edu
}

Received: March 23, 2012

Accepted: July 19, 2012

Online Published: July 30, 2012

doi:10.5539/ijef.v4n9p87

URL: http://dx.doi.org/10.5539/ijef.v4n9p87

\begin{abstract}
This paper provides evidence of merger timing induced by investors' overoptimism. We distinguish between hot and cold merger markets and examine the movements of bidding firms' stock prices, around, before and after mergers announcements. Our results provide strong evidence that mergers are driven by stock market valuation and that these events occur during periods when investors are highly overoptimistic and react irrationally to a merger announcement. We find evidence that bidders' managers are aware of the overvaluation of their firms and act rationally by timing their mergers and paying with stock. The market can however, correct itself when merger results start to appear.
\end{abstract}

Keywords: mergers and acquisitions, market efficiency, timing

\section{Introduction}

Merger activity has fluctuated throughout the periods. This fluctuation poses a challenge to the theory of mergers to explain the timing or determinants of the aggregate merger activity. Market timing is a relatively old idea that is having a new surge of popularity in the academic literature.

Many authors studied the timing question, and a different economic explanation was associated to each merger wave. The 1960s wave was a conglomerate wave, i.e. involving firms from different industries. During this wave, well-managed bidders built up diversified groups by adding capital and know-how to the acquired firms (Rumelt 1974, Meeks 1977, Steiner 1975). The 1980s wave was argued to be a hostile takeover wave. Many acquirers were financiers, and the medium of payment was often cash rather than stock. In these takeovers, raiders financed by bank debt and junk bonds acquired and split up the very same conglomerate assembled in the 1960s, because the conglomerate organization was no longer efficient (Jensen 1986, Blair, 1993, Bhagat, Shleifer and Vishny 1990). In the wave of the 1990s, most deals were for stock and were intended to consolidate major industries since the acquirers and targets were typically in the same industries (Holmstrom and Kaplan, 2001). The waves of the 1960s and 1990s were similar in that the medium of payment was generally stock and both occurred during periods of very high stock market valuations. In the $1980 \mathrm{~s}$, in contrast, the valuations were lower.

Since each wave rely on a special story for every decade, few attempts were done to find a theory that unifies these different stories. The first trend of studies relied on a neoclassical arguments to explain merger waves. This explanation is consistent with wealth creation. Hence, Mitchell and Mulherin (1996), Andrarde et al. (2001) distinguished different economic shocks and deregulation and controlled for the occurrence of merger waves inside the corresponding industries to try to explain respectively the 1980s and 1990s waves.

Later on, Shleifer and Vishny (2003) give a behavioral explanation to merger clustering in certain time periods. The authors built on an idea dating back to Nelson (1959). This idea could probably better explain the underperformance of acquirers in the long run (Note 1). Nelson (1959) studies the merger waves in the United States and proposes that merger expansion was not only a phenomenon of prosperity, but that it was also closely related to the state of the capital market. He points out that two reference cycle expansions, unaccompanied by a strong upswing in stock prices were marked by the absence of merger revival. In other words, the author suggests that stock market valuation is a key driver of the market for corporate control. The authors develop models in which merger waves are correlated with high stock market valuations. They argue that these waves result from managerial timing the market overvaluations of their firms. This theory has not been among the 
leading theories of mergers, even though in surveys, managers continue to offer at least some support for this idea (see Graham and Harvey, 2011).

While mergers have been studied extensively, only few papers both posit a cause for the fact that mergers occur in waves and the results of these studies are still controversial. Consequently, we know comparatively little about the characteristics of merger participants in waves, whether waves are generated by clustering of asset reallocation or instead by distortional behavior. Ultimately, the question of whether mergers in waves are different from those outside waves, has received even less attention. By investigating this new aspect, this study attempts to increase our understanding of merger waves. In fact, because of the concentration of merger activity within waves, understanding merger waves and how they are different from other merger activity will further our knowledge of the sources of value in mergers. Finally, by illustrating how mergers differ inside compared to outside waves, our results have implications for the way mergers are studied.

This study is related to a number of distinct literatures. It adds to the empirical literature that examine trends in merger and acquisition activity, in that it integrates both (1) the behavioral explanation and (2) the neoclassical explanation that are argued in the literature to be the major theories that could explain merger waves (previous studies examine one theory at a time). Moreover, we integrate the managerial motivations and hubris hypothesis, as factors that could enhance the effects of the two other hypotheses to create a wave.

To analyse whether mergers in waves are different from those outside waves, we distinguish between the different merger market status: hot and cold, and focus on the stock patterns during each market status. To understand the merger timing process, we control for the acquirer performance in the periods of one year before and one year after the merger announcement, and over the three days surrounding the announcement. This procedure allows us to control for the information dissemination that could occur before and even after a merger announcement and completion. We use firm, transaction and market specific variables to come up with a set of common variables that could be associated to hot and cold cycles. By studying the variation in merger quality over the different merger cycles, we can shed light on the reasons why and when acquisitions occur.

We base our empirical analysis on a data set of acquisitions made by publicly traded Canadian acquirers. Our interest for Canadian bidders stems from the following figures. According to Thomson Financial, in the year 2000 , Canada ranked $3^{\text {rd }}$ in terms of the number of completed deals and $5^{\text {th }}$ in terms of the value of the deals. Moreover, between 2001 and 2005, Canada ranked between $4^{\text {th }}$ and $6^{\text {th }}$ in terms of the number and value of the completed transaction. Canada realized an annual compounded growth of $31 \%$ (Note 2) over the period 1991-2000, outstripping the $27 \%$ growth in the United States (Note 3). This dramatic increase in the M\&A trend in Canada makes it an interesting context to examine the puzzle of the timing of M\&As. Our sample includes 462 transactions involving public and non-public targets, between January 1988 and December 2002.

Our results provide strong evidence on the existence of merger timing. Our findings demonstrate that investors' overoptimism is a key driver of the acquisition process. These transactions occur during periods when investors are highly overoptimistic and react irrationally to a merger announcement. Consistent with Shleifer and Vishny (2003) arguments, we find evidence that the bidders' managers are aware of the overvaluation of their firms and act rationally by timing their mergers and paying with stock.

During hot merger markets, acquirers significantly outperform the market benchmarks during the pre-merger year. The overperformance is even higher for firms paying with majority stock (more than $50 \%$ stock is used in payment). Moreover, there is a dramatic reversion in performances in the year following the announcement, especially for majority stock payers. This reversion is high enough to wipe out the prior gains for this category of acquirers.

Another finding is that in hot markets and even when stock is used in payment, the announcement stock reaction is positive. This result suggests that in hot markets, investors have unrealistic expectations about the synergies from the merger.

The remainder of this work is structured as follows. The following section summarises the literature on the possible origins of merger timing and expose the assumptions on which we build our study. Section 3 presents our data. Section 4 describes the methodology and results. The final section concludes.

\section{Literature Review on the Possible Sources of Mergers and Acquisitions Timing}

The timing of a merger could have two main causes: investors' sentiment and asymmetric information, and economic shocks. Managerial motivations are identified as a third cause that could enhance the effect of the two other hypotheses to create a wave. 


\subsection{Investors' Sentiment and Asymmetric Information}

This concept dates back to Hickman (1953), and was more developed by the literature on initial public offerings (IPOs) and seasoned equity offerings (SEOs), which suggests that in hot markets (Note 4), investors may be overly optimistic. Choe, Masulis and Nanda (1993) discuss the clustering of equity issues in certain time periods. They also suggest that certain periods offer "windows of opportunity" in which capital raising can be done at a lower cost. In the same context, Myers and Majluf (1984) argue that managers can time their equity issues for periods when the level of asymmetric information is low. This is the best way to reduce the information costs. Bayless and Chaplinsky (1996) suggest that periods of relatively high issue volume should correspond to periods of reduced information costs and find evidence of over-optimism in hot markets. Loughran, Ritter and Rydqvist (1994) report that issuing in hot markets may be worse than average for the investors. Since managers are able to time their issues, they profit from investors 'optimism (Note 5).

In line with these arguments, mergers and acquisitions are likely to be financed with equity in hot periods. Shleifer and Vishny (SV) (2003) argue that stock market valuation drives mergers and acquisitions. Since a special story was developed to explain different takeover waves, SV proposed that the theory of stock market valuation can be a unified theory for these different stories. The authors propose a model based on the financial market inefficiencies, in the sense that some firms are misvalued. They suggest that "managers are completely rational, informed, understand stock market inefficiencies and take advantage of them in part through merger decisions" (page 296). In a way, their main idea is the opposite of the hubris hypothesis developed by Roll (1986) who suggests that in corporate takeovers, stock markets are rational while managers are not.

Since managers are rational, informed and operate in a less rational market, they understand the stock market mechanism and can evaluate the deviation, from efficiency in the short run, of their stock and the target's. They are also able to estimate the perceived synergies and they employ their knowledge to maximize their own wealth. SV (2003) analyze how irrational shifts in investor sentiment can affect the takeover market. They argue that mergers and acquisitions may occur for the sole reason that overpriced equity can be used as means of payment. Negative net present value projects may be undertaken when equity is perceived as "cheap" and positive net present value projects may be foregone when equity is perceived as "expensive".

This mispricing is suggested as an explanation of the long-run performance of acquiring firms. In fact, SV argue that the markets can correct themselves in the long-run but in the short-run, investors can be fooled and do not react to manipulation. The authors suggest that when market or industry inefficiencies are high, most of the acquisitions are made for stock. They suggest that earning manipulation and insider selling are some of the operations done by the bidders in stock acquisitions, which provide support for the overvaluation of these bidders. In other words, investor's sentiment affects stock market valuation. This misvaluation can be attributed to entire industries, sectors or group of firms with the same characteristics. According to SV (2003), the perceived synergy is "just the lubricant that greases the wheels of the mergers and acquisitions (M\&A) process it might be invented by investment bankers or academics and have little to do with the reality of what drives actual acquisitions" (page 298).

SV suggest that short-run market perceptions may lead at least in part, to the takeover activity. In fact, they argue that if the market believes that the acquisition can drive positive synergy without being over-optimistic, bidding shareholders can realise some gain from its higher valuation. These gains will be diluted in the long-run, when the long-run prices return to efficiency.

SV also suggest that in the long-run, bidding firms can gain, even when the observed stock returns are negative, if the price they pay to the target is lower than the perceived synergy from the acquisition. They argue that without the acquisition, returns would have been more negative. This result will especially prevail when the initial returns observed are important.

Rhodes-Kropf and Viswanathan (RKV) (2004) also propose that high market valuations (period of time when average market-to-book ratios are high) drive stock mergers and cause intense merger activity. SV derive the same conclusion by assuming that acquirer managers are rational, evolving in an irrational stock market. RKV also consider the two components of misvaluations: a firm-specific component and a market-wide component. Moreover, they consider the possibility of a sector specific mispricing and suggest that this component could explain the diversifying mergers.

Jensen (2004) suggests that high equity valuations may cause suboptimal action that could take the form of mergers. In fact, CEOs take advantage in maintaining unreasonably high stock prices, even if their strategies could destroy value, at the end. 
Rhodes-Kropf, Robinson and Viswanathan (RKRV) (2005) build on RKV and SV and model the misvaluation to explore the correlation between valuation, merger activity and the method of payment in merger transactions. They find a strong support to the idea that mergers are caused by the deviation from fundamental values which is captured by the two first components that result from the decomposition of the $\mathrm{M} / \mathrm{B}$.

Dong et al. (2006) also provide evidence that irrational market misvaluation influences different aspects of the takeover market. They argue that stock market misvaluation affects the volume and characteristics of takeover transactions. Moreover, they report that the misvaluation of bidders and targets influences the method of payment, the bid premium, hostility of the target to the offer, the offer success, the announcement and the long-run abnormal returns

Ang and Cheng (2006) provide empirical evidence supporting the market-driven acquisition theory proposed by SV (2003). In particular, their results suggest that acquiring firms are more overvalued than non-acquiring firms, acquirers are more overvalued than their targets, and successful acquirers are more overvalued than unsuccessful acquirers. Moreover, their results show that the overvaluation increases the probability of firms of becoming acquirers and using their own stocks as a medium of exchange.

Friedman (2006) suggest that one of the consequences of the stock market driven acquisitions hypothesis of SV, is that overvaluation increases the premium paid to the target in equity mergers but not in cash mergers.

Hypothesis H1: If managers are able to time their mergers when investors are over-optimistic and if investors' optimism encourages firms to make bad acquisitions, then the announcement abnormal returns should be higher in hot markets than at other periods. The post merger performance should reverse and should be worse in hot markets than in cold markets.

\subsection{Industry Effects}

The neoclassical theory suggests that mergers generate synergies. A recent strand of literature builds on this theory. Mitchell and Mulherin (1996) analyze two different issues observed in mergers in the 1980s. The first is that mergers occur in waves and the second is that there is an industry clustering within a wave. They conclude that the interindustry patterns in takeovers and restructuring reflect the relative economic shocks to the industries. Their results support the view that a major influence on the takeover activity of the 1980s was a combination of broad underlying economic and financial forces. The authors argue that the observation of industry-specific merger waves occur as a response to regulatory, technological and economic shocks. This gives support to the assumption that industries have a tendency to restructure in concentrated periods of time.

Andrade, Mitchell and Stafford (2001) extend the Mitchell and Mulherin results. Their evidence supports an impact of industry shocks. The authors suggest that in contracting industries, acquiring firms appear to be those with better performance, lower capacity utilization, and lower leverage.

Gugler et al. (2006) challenge this theory and argue that the industry shock hypothesis ignores the correlation between merger waves and the stock market booms. Gugler et al. (2006) suggest two hypotheses to associate these events together. Either a single exogenous event causes both series of industrial merger waves and the stock market boom. The other suggestion is that the stock market itself causes a series of industry merger waves.

In a theoretical paper, Lambrecht (2004) analyzes the timing of mergers that are motivated by economies of scale. The author argues that firms have an incentive to merge in periods of economic expansion and suggests that the merger synergies are an increasing function of product market demand.

Hypothesis H2: If shocks tend to increase the synergies from takeovers, then we could expect bidder gains to increase at the announcement and during the subsequent periods.

Consequently, mergers occurring in shock periods should correspond to periods of hot markets and result in a positive correlation between announcement returns and hot merger markets. In this case, the increase in stock prices should not reverse over the subsequent periods. In fact, if mergers are made to exploit synergies, then they should add value to the firm. However, if mergers are motivated by managers' objectives then mergers occurring in hot periods will be worse than those occurring in cold periods. At least after mergers that are completed in hot markets, we should observe weak performance.

\subsection{Managerial Motivations}

Managerial motivations can also be a source of merger timing. The literature contains seeds of arguments that waves could be started and/or continued by either managerial discretion or manager irrationality. 


\subsubsection{Managerial Discretion}

The conflict of interest hypothesis predicts that bidder managers knowingly engage in acquisitions that will profit them personally even if their actions will result in stock price decline and consequently decrease shareholders' wealth. By making such operations, managers can take advantages from greater job security. Moreover, expanding the firm beyond its optimal size (size that maximizes shareholder wealth), managers can benefit from greater power by increasing the resources under their control, and changes in management compensation are positively related to growth (as measured by sales growth).

Jensen (1988) suggests that this phenomenon could occur for example, when managers hold little stock in their companies and when their compensation encourages them to make decisions to increase accounting earnings rather than the value of the firm. This phenomenon could also occur when managers do not understand the mechanisms that determine the stock values and therefore do not make the right investment decisions.

Another factor that can give incentives to managers to have a bias toward growth is the tendency of firms to reward middle managers through promotion instead of year-to-year bonuses. Growth can afford these managers with better positions that will make them benefit from the reward that goes with the promotion.

Morck et al. (1990) argue that if making an acquisition prevents a company from being a target and being acquired, managers may make such investments to preserve their positions and private benefits. These decisions are defensive strategies and could occur even if the acquisition is not profitable. Gorton, Kahl and Rosen (2009) apply agency theory to develop a theory of merger waves based on defensive mergers by independence-minded managers. In their model, an economic shock increases the likelihood of future mergers, but the wave results from a rash of medium-sized firms preemptively buying other firms to decrease the chance of becoming a target themselves.

Gugler et al. (2006) examines the link between managerial motivations and merger waves. The authors suggest that during stock market bubbles investors are overoptimistic, and tend to accept any news as good news, which changes the cost to managers from announcing unprofitable mergers. Gugler at al. (2006) suggest that announcing the same mergers in normal conditions would result in a fall in the acquiring firm's share, which is large enough to prevent the managers from undertaking the merger. However, announcing the transaction during bubbles would result in a positive stock market reaction. Investors' overoptimism is combined with managers incentives since this optimism frees managers to finance unprofitable mergers by issuing shares and also frees their hands to use more of their cash-flows to finance mergers.

Hypothesis H3a: If managerial discretion motivates mergers, we also would expect positive announcement reaction (or at least not negative) followed by a reversion after the merger completion.

\subsubsection{Hubris Hypothesis}

The hubris hypothesis is a second hypothesis that can determine managers' motivations. This hypothesis predicts that managers tend to overestimate their ability to manage the target firm. Thus, they mistakenly believe that the takeover will increase the stock price of the bidder firm. Therefore, they overpay the target. Roll (1986) argues that the premium paid to the target is a transfer from the bidder firm. Under a strong market efficiency hypothesis, Roll (1986) suggests that the target market price reflects the full value of the firm. If the bidder overestimates the target because of hubris (i.e. the excessive self-confidence (arrogance, pride) of the managers), he could overpay for the target. In fact, acquirer managers make this mistake because they overrate the synergistic gains from acquisition. This is due to their high confidence in their own managerial abilities.

The hubris hypothesis can be extended to the case of merger waves. In periods of shock or if high stock market valuations occur, the variance of the distribution of possible target valuation estimates increases. This generates a larger mass of valuation estimates exceeding the threshold for making a bid. The result is that some hubris-filled managers observe large positive valuation errors and make bids, creating a wave.

Hypothesis H3b: If mergers are driven by managers' hubris, we should observe a stock price increase in the year prior to the merger announcement and a reversion in the post-merger period.

\section{Data}

\subsection{Sample Selection}

We obtain our data sets of mergers and acquisitions from the Thomson Financial SDC Platinum database (SDC). The data meets the following criteria:

1- We consider only transactions made by Canadian firms; 
2- The announcement date is from 1988 to 2002 inclusively;

3- The acquirer must be a public company traded on the Toronto Stock Exchange (TSE);

4- The percent of shares acquired in the transaction should be greater than $50 \%$ of the target;

5- The deal must have been completed;

This selection gives us an initial sample of 3069 transactions. As a second step, only the transactions classified as: mergers or acquisitions of majority interest are kept. We exclude all the cases defined as an acquisition of assets, an acquisition of certain assets, a buyback, or a recapitalization. This results in a sample of 1111 transactions.

Financial information and daily stock returns are extracted from Compustat and the TSE Western Database respectively. We retain only the companies with data in both databases. The final sample comprises 462 transactions involving 253 acquirers.

\subsection{Sample Characteristics}

Table 1. Descriptive Statistics

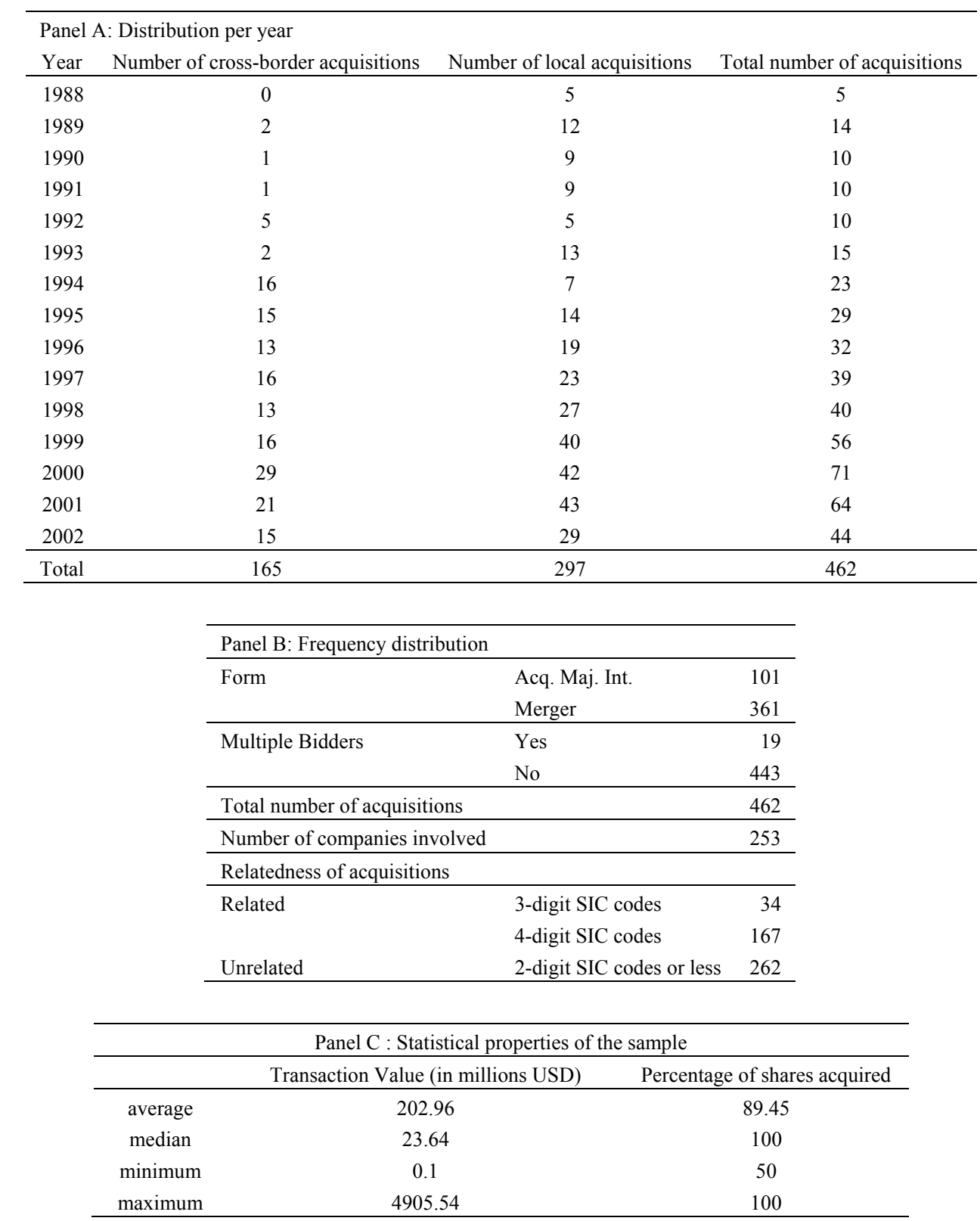




\begin{tabular}{|c|c|c|}
\hline \multicolumn{3}{|c|}{ Panel D: Sample frequency of bidders by primary SIC code } \\
\hline SIC Codes & Number & Percentage of total \\
\hline 10 Minerals & 152 & $32.90 \%$ \\
\hline 20-39 Manufacturing & 112 & $24.24 \%$ \\
\hline 40 Communications & 53 & $11.47 \%$ \\
\hline 50 Trade & 14 & $3.03 \%$ \\
\hline 60 Financial & 53 & $11.47 \%$ \\
\hline \multirow[t]{2}{*}{ 70-89 Services } & 68 & $16.86 \%$ \\
\hline & 462 & $100.00 \%$ \\
\hline
\end{tabular}

Table 1 describes the 1988 to 2002 sample of acquisitions obtained from the Securities Data Corporation. The transaction needs to be completed by public Canadian bidders traded on the Toronto Stock Exchange. Only the transactions where majority is acquired are included in the sample. Panel A represents the distribution across announcement year. In Panel B we report the form of the acquisitions (whether the transaction in an acquisition of majority interest or a merge), the existence of multiple bidders and the activity relatedness of the bidder and target according to the sic codes. We distinguish between related activities; i.e. companies have 4-digit or 3-digit or 2-digit in common; activities are unrelated otherwise. 361 out of 462 transactions in our sample are mergers. More than $60 \%$ of the transactions are between related businesses. We also note that the presence of competing bidders is rare (only $4 \%$ of the cases).

Panel $\mathrm{C}$ gives the statistical properties of the transactions. Mergers and acquisitions values vary highly; the average is 202.96 million USD, while the median is 23.64 million USD. The mean percentage of shares acquired is $89.45 \%$.

Panel D presents acquisitions by primary SIC code. In Canada, over $23 \%$ of the 462 transactions are in the resources industry (SIC 1000). The rest of the transactions are distributed across several industries.

\section{Methodology}

\subsection{Identification of Hot, Cold and Normal Markets}

We define hot and cold mergers and acquisitions (M\&A) markets using the aggregate number and value of M\&A occurring during the period from January 1988 to December 2002 obtained from Crosbie \& Co., Directory of Mergers \& Acquisitions in Canada, Annual Edition.

We use two definitions of aggregate value: nominal dollar and real dollar. Real dollar value is monthly nominal value of M\&A deflated by the monthly Consumer Price Index (CPI). We rank a three-month moving average of M\&A value (number) into quartiles. We define hot periods as at least three consecutive months where the value (number) of M\&A exceeds the upper quartile. The cold periods are at least three consecutive months where the value (number) of M\&A stands below the lower quartile. The M\&A that fall between the upper and the lower quartiles are classified in the normal period (Note 6).

More than $78 \%$ of our sample receive the same classification into the hot, cold and normal markets, whether we use a rank based on the number or value (nominal and real) of the aggregate M\&A in Canada. Consequently, the remainder of this paper focuses on results using a classification based on the aggregate number of M\&A.

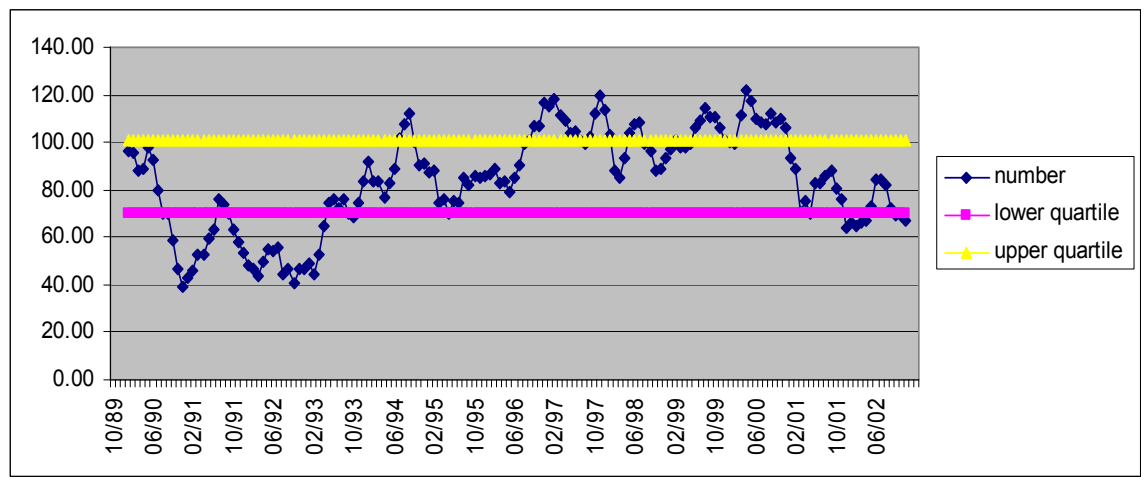

Figure 1. Hot and Cold Markets classified by the number of transactions 
Figure 1 plots the classification of hot and cold merger markets as measured by a three month moving average of the aggregate number of mergers and acquisitions.

Table 2. Market classification and duration (in months) based on the number of mergers and acquisitions

\begin{tabular}{llr}
\hline & & \\
& Period & Duration \\
\hline Cold & $09 / 90-06 / 91$ & 9 \\
& $10 / 91-04 / 93$ & 19 \\
& $12 / 01-05 / 02$ & 6 \\
Hot & $09 / 96-01 / 98$ & 17 \\
& $06 / 99-12 / 00$ & 19 \\
\hline
\end{tabular}

Table 2 shows that while hot markets are concentrated in a five-year period (between 1996 and 2000), cold markets occur at both the beginning and the end of the sample period. In our sample, 159 of 462 transactions occur during hot markets and are concentrated in 36 months out of 168 months that compose the total period of study. 53 mergers and acquisitions occur in cold markets during 34 months. The remaining 250 transactions take place in normal markets.

\subsection{Abnormal Returns for M\&A in Hot, Cold and Normal Markets}

In a discussion of the choice of M\&As performance measurement, Sudarsanam (ed., 2003) points out that the time scale for assessing the wealth increase is an important consideration. He argues that the need to conduct a long-term analysis depends on ones' view of the efficiency of the capital markets. If they are informationally efficient, the stock market reaction to the announcement will capture the future benefits and costs of a merger. Hence, a short-term event window will reflect all the valuation effects of the merger. A short event window supposes that the market can fairly quickly, if not instantaneously integrate the probability of realizing acquisition benefits, in the stock prices. The author argues that various studies on the stock market reaction to events (initial public offerings, release of accounting information, rights issues...) show, that on the contrary, stock markets continue to react after the announcement day. This means that the market takes time to digest the information or awaits more information to evaluate the benefits from the event and the probability of their realization. For this reason, more recent empirical studies extended the event window to three, five or even seven years.

Sudarsanam argues that lengthening the event window to several years will create other problems, since the longer the window of study, the greater are the chances that strategic, operational and policy changes could occur during this window, which will impact the valuation and reduce the reliability of the results of the performance that is attributable to the merger solely.

Foerster and Karolyi (1999) report that there may well be information dissemination (to the market participants), prior to the announcement of an event, around an event and even after its completion (Note 7). For that reason, they do not recommend the use of a short-window study around the announcement dates and suggest the use of a window of one-year prior and one year subsequent to the event. They argue that this methodology allows deriving an overall picture that cannot emerge from a short-window study. Thus, if we choose a short-window of study, around the announcement date, as it is done in the existing literature (Note 8), we will not be able to capture the information dissemination prior to the announcement and after the merger completion.

To circumvent the problem of the choice of an event window, we base our tests on three windows as suggested by Foester and Karolyi (1999), the period of 1 year prior to the announcement $(-366,-2)$, the three days around the announcement $(-1,1)$ and a period of 1 year following the announcement $(2,366)$ (Note 9$)$. We consider day $\mathrm{t}=0$, as the announcement date.

The abnormal returns are computed using the market model, which assumes a linear relationship between the return of any security to the return of the market:

$$
\mathrm{R}_{\mathrm{it}}=\alpha_{i}+\beta_{i} \mathrm{R}_{\mathrm{mt}}+e_{i t}
$$

where $\boldsymbol{t}$ is the time index, $\boldsymbol{i}=1, \ldots, \mathrm{N}$ stands for security, $\mathrm{R}_{\mathrm{it}}$, and $\mathrm{R}_{\mathrm{mt}}$ are the returns on security $\boldsymbol{i}$, and the market respectively during period $\boldsymbol{t}$, and is $\hat{e}_{i t}$ the error term for security $\boldsymbol{i}$.

The event windows are defined as the period from 1 day prior to 1 day after the announcement, a second period, which runs between 2 and 366 days prior to the announcement day, and a third period that runs between 2 and 
366 days after the announcement. Equation (1) is estimated over an interval of $(-485 ;-120)$ days before the beginning of each event period. With the estimates of $\alpha_{i}$ and $\beta i$ from equation (1), we can predict a "normal" return. The prediction error referred to as the abnormal return (AR), is then calculated:

$$
\mathrm{AR}_{\mathrm{it}}=\mathrm{R}_{\mathrm{it}}-\hat{\alpha}_{\mathrm{i}}-\hat{\beta}_{\mathrm{i}} \mathrm{R}_{\mathrm{mt}}
$$

In order to test for the persistence of the impact of the event during a period $T_{2}-T_{1}$, the abnormal return is added to obtain the cumulated abnormal returns $\left(C A R_{i}\left(T_{2}-T_{1}\right)\right)$ for security $\boldsymbol{i}$ over the period $T_{2}-T_{1}$. This calculation is done for three event windows $(-366 ;-2),(-1 ; 1),(2 ; 366)$ and is followed by a calculation of the mean cumulative abnormal returnsm (Note 10).

Moreover, for additional robustness, we estimate the abnormal returns using the buy-and-hold abnormal returns. The index returns are used as a benchmark.

Results of both models converge. In the remaining of this paper we comment the results from the market model measured toward the equal-weighted market index (Note 11).

Table 3. Abnormal returns, for mergers and acquisitions in Hot, Cold and Normal markets

\begin{tabular}{|c|c|c|c|c|}
\hline $01 / 88-12 / 02$ & Full Sample & HOT & COLD & NORMAL \\
\hline \multicolumn{5}{|l|}{$\operatorname{CAR}(-366 ;-2)$} \\
\hline Mean & $14.19 \%$ & $22.99 \%$ & $6.82 \%$ & $9.72 \%$ \\
\hline Median & $8.67 \%$ & $15.51 \%$ & $1.55 \%$ & $7.46 \%$ \\
\hline $\mathrm{t}:$ Mean $=0$ & $6.55^{* * *}$ & $5.44^{* * *}$ & 1.54 & $3.50 * * *$ \\
\hline $\mathrm{t}$ : Hot - Cold $=0$ & & & $2.73 * * *$ & \\
\hline Z: Hot - Cold $=0$ & & & $2.77 * * *$ & \\
\hline $\mathrm{t}:$ Hot - Normal $=0$ & & & & $2.74 * * *$ \\
\hline Z: Hot - Normal $=0$ & & & & $2.55^{* *}$ \\
\hline $\mathrm{N}$ & 439 & 154 & 46 & 239 \\
\hline \multicolumn{5}{|l|}{$\operatorname{CAR}(-1 ; 1)$} \\
\hline Mean & $1.20 \%$ & $2.20 \%$ & $0.93 \%$ & $0.41 \%$ \\
\hline Median & $0.28 \%$ & $0.55 \%$ & $0.06 \%$ & $0.07 \%$ \\
\hline $\mathrm{t}:$ Mean $=0$ & $2.74 * * *$ & $2.88^{* * *}$ & 1.14 & 0.66 \\
\hline $\mathrm{t}$ : Hot - Cold $=0$ & & & 1.15 & \\
\hline Z: Hot - Cold $=0$ & & & 0.67 & \\
\hline $\mathrm{t}:$ Hot - Normal $=0$ & & & & $1.83 *$ \\
\hline Z: Hot - Normal $=0$ & & & & 1.42 \\
\hline $\mathrm{N}$ & 396 & 148 & 42 & 206 \\
\hline \multicolumn{5}{|l|}{$\operatorname{CAR}(2 ; 366)$} \\
\hline Mean & $-15.05 \%$ & $-20.29 \%$ & $-1.66 \%$ & $-12.21 \%$ \\
\hline Median & $-7.46 \%$ & $-14.98 \%$ & $-0.05 \%$ & $-7.43 \%$ \\
\hline $\mathrm{t}: \mathrm{Mean}=0$ & $-8.12 * * *$ & $-6.10 * * *$ & -0.54 & $-4.67 * * *$ \\
\hline $\mathrm{t}$ : Hot - Cold $=0$ & & & -1.11 & \\
\hline Z: Hot - Cold $=0$ & & & $-2.48 * * *$ & \\
\hline $\mathrm{t}:$ Hot - Normal $=0$ & & & & $-2.93 * * *$ \\
\hline \multirow[t]{2}{*}{ Z: Hot - Normal $=0$} & & & & $-2.33^{* *}$ \\
\hline & 462 & 159 & 53 & 250 \\
\hline
\end{tabular}

$*, * *, * * *$ refer to $10 \%, 5 \%$ and $1 \%$ significance levels.

Table 3 presents the average cumulative daily abnormal returns for the total sample of M\&A in hot, cold and normal markets. The observation of the bidder performance in the year preceding the announcement shows that bidders in all markets register an important run-up in prices that is significantly higher in hot markets compared to cold and normal markets. The average CAR $(-366 ;-2)$ is $22.99 \%$ for hot bidders, $6.82 \%$ for cold bidders and $14.19 \%$ for the full sample. Dong et al. (2006), RKRV (2005) argue that firms have incentives to make acquisitions when their stocks are overvalued. If hot stock markets mean that more firms have overvalued stock, then this could lead to a correlation between hot markets and mergers. In this case, a rational stock market would react to a merger announcement as evidence that a firm may think its stock is overvalued. This could lead to 
negative announcement reaction with no reversion in the later periods. Correlation between mergers and stock prices could also reflect over-optimism. In this case, we should observe a more positive reaction to merger announcements during hot stock markets followed by a reversion in the subsequent periods.

Results in table 3 demonstrate that the opposite phenomenon occurs, the reaction to mergers announced during the cold and hot markets are positive and higher (but not significantly different) during hot markets compared to cold ones. On average, the CAR $(-1,1)$ is $2.20 \%$ for hot market acquirers, $0.93 \%$ for cold market acquirers and $0.41 \%$ for normal market acquirers. The announcement returns are significantly different between hot and normal markets. These results indicate that hot market acquirers receive a more favourable response on average to an acquisition announcement.

The average CAR $(-1 ; 1)$ for the full sample is consistent with the literature. Eckbo (1986) finds positive and significant abnormal returns around merger announcements. Our results show a significant and positive abnormal return of $1.20 \%$, which is comparable to the results of Eckbo (1986).

In the post-announcement year, the returns reverse and hot market acquirers underperform significantly cold market acquirers. CAR $(2 ; 366)$ is significantly different between hot and cold markets and hot and normal markets. CAR $(2 ; 366)$ is $-20.29 \%$ in hot markets compared to $-1.66 \%$ in cold markets and $-12.21 \%$ in normal markets. (Note 12)The reversion of the post-announcement abnormal returns is dramatic compared to those reported in studies that used US data.

The post-merger abnormal returns for the overall sample in our study are $-15.05 \%$ as a mean and $-7.46 \%$ as a median. Ang and Cheng (2006) report one-year abnormal returns of $-3.76 \%$. Bradley and Sundaram (2006) report one-year abnormal returns of $-2.48 \%$. Our results are however, comparable to the one of Friedman (2006) who found a one-year post merger abnormal return of $-15.01 \%$. Moreover, the level of run-up in our sample (14.19\%) is comparable to the results of Bradley and Sundaram (2006) (the run-up is 19.01\%).

The positive reaction to the merger announcement in hot market followed by a high negative and significant performance corroborates the theory of investors' overoptimism. This reversion phenomenon occurs when bidders' results replace optimism. This could shed light on stock overvaluation in hot cycles. Our results are also consistent with the hubris hypothesis (Roll, 1986). Managers of firms that registered good performance may believe that they can create value in situations that the markets judges to be negative net present value, this should also lead to the reversion observed. Moreover, since merger decisions are made by managers who could have personal interests, the results could also be in favor of the managerial motivations hypothesis. In fact, managerial motivations may exacerbate the effect of investors' overoptimism on the abnormal returns following the announcement. Even if these theories give different explanations of why mergers occur, they have the same predictions toward the stock price movements.

To this point, our results allow rejecting only the neo-classical theory of mergers, which predicts that hot merger markets occur following shocks and allow creating common synergies. This theory suggests that mergers during hot periods should be better than mergers at other times, which is not confirmed by our results since post-merger performance is significantly worse in hot markets compared to the cold ones (z-test significant at $1 \%$ level) and to what we called 'normal' periods ( $\mathrm{t}$-test and z-test significant at $1 \%$ level).

\subsection{The Means of Payment}

If hot markets are characterized by stock overvaluation then stock is more likely to be used as a means of payment in these periods. We distinguish between payments with majority stock, i.e. more than $50 \%$ of the transaction value is paid in stock and payments where less than $50 \%$ stock is used in payment.

Table 4. Summary statistics of the means of payment in the cold and hot markets

\begin{tabular}{llll}
\hline Percentage of stock in payment & Less than $50 \%$ stock & More than $50 \%$ stock & Total \\
\hline $\begin{array}{l}\text { Period } \\
\text { HOT }\end{array}$ & 94 & & \\
Number of firms & $49.12 \%$ & 65 & 159 \\
$\begin{array}{l}\text { Percentage } \\
\text { COLD }\end{array}$ & 43 & $40.88 \%$ & $100.00 \%$ \\
Number of firms & $81.17 \%$ & 10 & 53 \\
Percentage & & $18.83 \%$ & $100.00 \%$ \\
\hline
\end{tabular}


Table 4 demonstrates a more intensive use of equity as a transaction currency in hot markets, more than $40 \%$ of the acquirers in hot periods pay the transaction value with more than $50 \%$ stock, compared to $18 \%$ in cold markets.

To investigate properly the link between the bidders stock movements and the means of payment, we study the cumulative abnormal returns in each period. As in table 4, we distinguish between firms that use stock to pay more than $50 \%$ of the transaction (we define this category as paying with majority stock, for the rest of the paper) and firms that pay with less than this percentage (Note 13).

Table 5. Abnormal returns, for mergers and acquisitions in Hot, Cold and Normal markets, decomposition based on the percentage of stock used in payment

\begin{tabular}{|c|c|c|c|c|c|c|c|c|}
\hline \multirow{2}{*}{$\frac{01 / 88-12 / 02}{\operatorname{CAR}(-366 ;-2)}$} & \multicolumn{2}{|l|}{ Full Sample } & \multicolumn{2}{|l|}{ HOT } & \multicolumn{2}{|l|}{ COLD } & \multicolumn{2}{|l|}{ NORMAL } \\
\hline & $\begin{array}{l}\text { Stock }<50 \% \\
\text { (1) }\end{array}$ & $\begin{array}{l}\text { Stock }>=50 \% \\
\text { (2) }\end{array}$ & $\begin{array}{l}\text { Stock }<50 \% \\
\text { (1) }\end{array}$ & $\begin{array}{l}\text { Stock }>=50 \% \\
\text { (2) }\end{array}$ & $\begin{array}{l}\text { Stock }<50 \% \\
(1)\end{array}$ & $\begin{array}{l}\text { Stock }>=50 \% \\
\text { (2) }\end{array}$ & $\begin{array}{l}\text { Stock }<50 \% \\
\text { (1) }\end{array}$ & $\begin{array}{l}\text { Stock }>=50 \% \\
\text { (2) }\end{array}$ \\
\hline Mean & $8.65 \%$ & $11.12 \%$ & $13.45 \%$ & $35.38 \%$ & $4.11 \%$ & $12.29 \%$ & $7.20 \%$ & $7.20 \%$ \\
\hline Median & $6.07 \%$ & $9.61 \%$ & $8.67 \%$ & $22.99 \%$ & $1.29 \%$ & $20.35 \%$ & $7.28 \%$ & $6.13 \%$ \\
\hline $\mathrm{t}: \mathrm{Mean}=0$ & $3.91 * * *$ & $3.35^{* * *}$ & $3.25^{* * *}$ & $4.49 * * *$ & 0.78 & 1.00 & $2.38 * *$ & 1.60 \\
\hline $\mathrm{t}:$ Hot - Cold $=0$ & & & & & 1.31 & 0.71 & & \\
\hline Z: Hot - Cold $=0$ & & & & & $1.87 * *$ & 0.32 & & \\
\hline $\mathrm{t}:$ Hot - Normal $=$ & & & & & & & 1.23 & $3.24 * * *$ \\
\hline Z: Hot - Normal $=$ & & & & & & & 1.26 & $2.68 * * *$ \\
\hline $\mathrm{t}:(1)-(2)=0$ & & -0.68 & & $-2.62 * * *$ & & -0.63 & & 0.00 \\
\hline$Z:(1)-(2)=0$ & & -1.37 & & $-2.20 * *$ & & -1.31 & & 0.48 \\
\hline $\mathrm{N}$ & 283 & 140 & 87 & 67 & 39 & 8 & 155 & 80 \\
\hline \multicolumn{9}{|l|}{$\operatorname{CAR}(-1 ; 1)$} \\
\hline Mean & $0.96 \%$ & $1.26 \%$ & $2.17 \%$ & $2.42 \%$ & $0.26 \%$ & $2.85 \%$ & $-0.29 \%$ & $-1.20 \%$ \\
\hline Median & $0.33 \%$ & $-0.33 \%$ & $0.64 \%$ & $-0.01 \%$ & $-0.15 \%$ & $4.78 \%$ & $-0.03 \%$ & $-1.32 \%$ \\
\hline $\mathrm{t}: \mathrm{Mean}=0$ & $2.30 * *$ & 1.33 & $2.56^{* *}$ & 1.36 & 0.26 & 1.24 & -0.64 & -1.08 \\
\hline $\mathrm{t}$ : Hot - Cold $=0$ & & & & & 1.03 & -0.10 & & \\
\hline Z: Hot - Cold $=0$ & & & & & 1.11 & -0.46 & & \\
\hline $\mathrm{t}$ : Hot - Normal $=$ & & & & & & & $2.76^{* * *}$ & $2.00^{* *}$ \\
\hline Z: Hot - Normal = & & & & & & & $1.69^{*}$ & 1.57 \\
\hline $\mathrm{t}: \quad(1)-(2)=0$ & & 0.92 & & -0.16 & & -1.06 & & 0.87 \\
\hline$Z:(1)-(2)=0$ & & 0.44 & & 0.53 & & -0.81 & & 1.18 \\
\hline $\mathrm{N}$ & 248 & 138 & 83 & 60 & 35 & 7 & 152 & 76 \\
\hline \multicolumn{9}{|l|}{ CAR $(2 ; 366)$} \\
\hline Mean & $-10.15 \%$ & $-10.41 \%$ & -15.94 & $-43.73 \%$ & $-4.39 \%$ & $-16.88 \%$ & $-6.51 \%$ & $-8.71 \%$ \\
\hline Median & $-4.38 \%$ & $-12.58 \%$ & -6.67 & $-25.70 \%$ & -0.01 & $-25.35 \%$ & $-5.03 \%$ & $-10.47 \%$ \\
\hline $\mathrm{t}: \mathrm{Mean}=0$ & $-4.61 * * *$ & $-3.86 * * *$ & $-3.64 * * *$ & $-4.28 * * *$ & -0.72 & $-2.28 * *$ & -2.54 & $-2.19^{* *}$ \\
\hline $\mathrm{t}:$ Hot - Cold $=0$ & & & & & -1.34 & -0.70 & & \\
\hline Z: Hot - Cold $=0$ & & & & & $-1.96 * *$ & -0.15 & & \\
\hline $\mathrm{t}$ : Hot - Normal $=$ & & & & & & & $-1.99 * *$ & $-3.31 * * *$ \\
\hline Z: Hot - Normal = & & & & & & & -1.35 & $-2.86^{* * *}$ \\
\hline $\mathrm{t}: \quad(1)-(2)=0$ & & 0.07 & & $2.74 * * *$ & & -1.28 & & -1.65 \\
\hline$Z:(1)-(2)=0$ & & 1.41 & & $2.48 * * *$ & & -1.45 & & $-1.82 *$ \\
\hline $\mathrm{N}$ & 295 & 138 & 93 & 69 & 34 & 8 & 155 & 76 \\
\hline
\end{tabular}

$*, * *, * * *$ refer to $10 \%, 5 \%$ and $1 \%$ significance levels.

Results in table 5 confirm the reversion phenomenon that occurs in the post-merger year compared to the pre-merger year. Results for the full sample do not reveal any significant difference between the abnormal returns of firms paying with majority of stock and firms paying with less stock. Bidders seem to register highly significant positive abnormal returns in the pre-announcement period, the mean CAR is higher than $8 \%$ whatever the proportion of stock used. This performance reverses in the year following the announcement, the mean CAR 
is $-10.41 \%$ if majority stock is used and $-10.15 \%$ if less than $50 \%$ stock is paid. These underperformances are highly significant.

Results on the announcement reaction suggest that investors do not seem to perceive better, the transactions paid with less stock (Note 14). In fact, the mean cumulative abnormal return surrounding the announcement is $1.26 \%$ in the case of majority stock payment and $0.96 \%$ otherwise. There is no significant difference between these performances.

This lack of difference in the performances of the full sample, according to the proportion of stock used together with the robustness of our results to any cut-off in the proportion of stock between $50 \%$ and $70 \%$, prove the importance of distinguishing between the hot and cold markets and to analyse the acquirers' performances in each market separately. Therefore, to investigate the consistency of this result, we consider each period individually.

The hot market reveals that acquirers paying with majority stock register higher over-performances in the pre-announcement period (35.38\%) compared to acquirers paying with less stock $(13.45 \%)$ and higher underperformances in the post-announcement year $(-43.73 \%$ compared to $-15.94 \%)$. These differences are statistically significant (Note 15).

Surprisingly, average announcement abnormal returns do not vary with the proportion of stock (average CAR (-1; 1 ) is $2.42 \%$ when majority stock is used and $2.17 \%$ otherwise). There is no significant difference in the market reaction based on the percentage of stock used and this result is robust to any variation in the proportion of stock used in payment, between $50 \%$ and $70 \%$ of the total amount of the transaction. For this reason, the Myers and Majluf (1984) signalling hypothesis does not seem to hold in hot markets.

We note that in normal markets, the prior overperformance is not the driver to a major stock payment, since we do not find any performance difference between acquirers with majority stock and those with minority stock. Moreover, contrary to hot markets, majority stock payers in normal markets register negative abnormal returns upon announcement, which is consistent with the signalling hypothesis. We also find that compared to normal market, acquirers in hot markets register significantly higher overperformances before the announcement, and during the announcement window, and register higher underperformances in the year following the announcement. The significance of the difference tests is particularity important when we compare majority stock payers. Inside the normal markets, the difference tests do not reveal an important significant difference in abnormal performances between majority and minority stock acquirers.

Results on the cold cycles indicate that abnormal returns in the pre- announcement year are much higher when the payment is made with stock, the mean is $12.29 \%$ compared to $4.11 \%$. The spread in the median is even higher, $20.35 \%$ compared to $1.29 \%$. However, the statistical tests do not reveal any significant difference, which is due to the relatively small sample size.

In the post-announcement year, stock market reacts in the same way to acquirers paying with majority stock in the cold period as to the ones in hot periods. They register a high and significant underperformance $(-16.88 \%$ as a mean and $-25.35 \%$ as a median). Acquirers paying with less that $50 \%$ stock register negative abnormal returns, not significantly different from zero.Results for the cold market also do not support Myers and Majluf (1984). The announcement reaction is much higher when the payment is made with majority stock ( $2.85 \%$ compared to $0.26 \%$ for the means and $4.78 \%$ compared to $-0.15 \%$ for the medians).

While results in table 3 reveal that announcing acquisitions in cold markets leads to lower price reactions, results in table 5 prove that paying with minority stock drives low positive reactions not significantly different from 0 and even negative reactions (the median is $-0.15 \%$ ). Results demonstrate that investors are more sceptical toward investment decisions in cold periods.

Comparing results for the two means of payment, within the cold period does not reveal any statistical difference. The lack of significance in the cold period tests is as mentioned above due to the small size of the sub-samples. Firms paying with more than $50 \%$ stock register performances not significantly different from bidders in hot markets paying with the same proportion of stock.

The presence of such a category of acquirers in the cold market could be due to the presence of an overvalued industry in the cold market. In fact, 6 of the 8 companies that paid with more than $50 \%$ stock belong to the mining industry. However, further exploration on industry valuation has to be done to allow concluding, if all the industry is overvalued or if the firms are individually overvalued. This test goes beyond the scope of this study.

While results for the overall sample do not reveal any significant difference when we compare the two means of payment, results for the hot market reveals highly significant differences. The lack of difference inside the cold 
market is due to the relatively small size of the sample. We also note a significant difference between the run-up and the post-merger performance (mark-up), with the z-test, when a proportion of less than $50 \%$ stock is used in payment. This evidence proves that distinguishing only between the means of payment as it is done in the literature is not enough, and proves that distinguishing between the merger cycles is as much important.

Our results provide support for the investors' overoptimism hypothesis since, in hot markets, announcement abnormal returns do not differ with the proportion of stock used to pay the transaction.

The previous tests document that Canadian acquirers time their acquisitions in periods when investors' overoptimism is high. Market and macroeconomic conditions at the acquisition time can affect investors' reaction to the announcement, since they influence their estimates of the acquirer valuation. To better explain the results of the previous section, we investigate the possible determinants of the performances realised in the preand post-announcement periods. We also try to find a characteristic set that could be associated with each cold and hot market. For this purpose we introduce market, transaction and firm-specific characteristics as explanative factors for the abnormal returns measured.

\subsection{Characteristics of Hot and Cold Merger Markets and Determinants of Bidder Performances}

To determine the characteristics of hot and cold markets, we include the variables defined below, related to bidder, target, transaction characteristics, and market related variables, that might influence the market reaction to a merger. These variables are summarized in appendix.

Bidder specific variables: an important characteristic that is present in our sample is that many bidders make a series of acquisitions while others make only a single takeover. Some researchers report that frequent acquirers are different from occasional acquirers (Shipper and Thomson (1983) and Fuller et al. (2002)), for that reason we will include a dummy for whether the bidder has made a single merger or if he has made other mergers in the year prior to the announcement or in the year after.

Moreover, we control for certain events that could occur during our window of study. Those events could be acquisitions of assets, acquisitions of certain assets or buybacks that are reported in SDC database but are not defined as mergers or acquisitions. However, as many bidders in our sample make such transactions in the same period when they engage in mergers and acquisitions, these events could bias our results. For this reason, we include a dummy variable to control for those parallel events; this dummy will take a value of 1 if the bidder makes acquisitions of certain assets or acquisitions of assets or buybacks during our window of study. To our knowledge, most of the earlier studies that report mergers and acquisitions short and/or long-run performance do not control for the presence of those confounding events.

We also control for certain ratios that are of major importance in the determination of the financial strength of the bidder. In fact, we will control for the Tobin's Q and the ratio of return on assets. Servaes (1991) among others has proven that a low Tobin's $\mathrm{Q}$ is associated with a high short-run reaction to the merger announcement. The ratio of return on assets (ROA) proxies for the financial performance of a firm. Morck et al. (1990) suggest that firms with better prior performance make better acquisitions.

Transaction related variables: we control for the forms of acquisition financing. We call financings made with more than $50 \%$ stock as made with majority stock.

Many studies document that diversifying mergers result in lower returns to the acquiring firm. For this reason, we control for merger diversification by using a dummy variable, which takes 1 if the acquirer and target have 3-digit sic code in common.

We also control for the ratio of target size to acquirer size. In fact, when the target involved in the acquisition is much smaller than the acquirer, we do not expect the acquisition to have an important impact on the future earnings of the bidder, and thus, the acquirer's stock price movements should be small.

To measure the relative size, we use the ratio of total market equity of the target to the total market equity of the acquirer. Wherever it is not available we use the ratio of total assets instead. If the information on the target is not available, we use the ratio of the acquisitions price to the total market equity of the acquirer.

Target specific variables: since the market reaction to a merger differs in function of the target type as suggested by Fuller et al. (2002), we distinguish between two groups of targets: public firms, in one hand, and private firms and subsidiaries, in the other hand.

Market related variables: we control for whether the merger or acquisition occurred in hot, cold or normal periods. Moreover, since reaction to a merger may be affected by the stock market conditions, we proxy for the 
general level of stock prices in the market by calculating and using the change in the TSX equal-weighted index (Note 16).

\subsubsection{Univariate Analysis}

Table 6. Bidder and transaction-specific characteristics in the hot and cold markets and the full sample

\begin{tabular}{|c|c|c|c|c|c|c|c|c|}
\hline & ALL & & COLD & & HOT & & $\begin{array}{l}\text { t-test } \\
\text { (hot-cold) }\end{array}$ & Z-test (hot-cold) \\
\hline & Mean & Median & Mean & Median & Mean & Median & t-stat & Z-stat \\
\hline \multicolumn{9}{|l|}{ Transaction variables } \\
\hline Shares acquired & 89.4598 & 100 & 85.2517 & 100 & 92.3163 & 100 & $2.64 * * *$ & $2.18^{* *}$ \\
\hline Relative value & 24.988 & 9.2608 & 18.0115 & 6.9747 & 26.238 & 11.3474 & 1.42 & 1.08 \\
\hline$\%$ Stock & 36.9921 & 0 & 23.0203 & 0 & 43.1592 & 37.5391 & $2.08^{* * *}$ & $2.96^{* * *}$ \\
\hline \multicolumn{9}{|l|}{ Bidder variables } \\
\hline Multi-acq (t-366) & 0.3384 & 0 & 0.2264 & 0 & 0.475 & 0 & $1.87^{*}$ & 1.37 \\
\hline Multi-acq $(\mathrm{t}+366)$ & 0.355 & 0 & 0.1509 & 0 & 0.55 & 0 & $2.89^{* * *}$ & $2.86^{* * *}$ \\
\hline $\mathrm{Nb}$ of acq of assets (t-366) & 0.5621 & 0 & 0.566 & 0 & 0.7405 & 0 & 1.07 & 0.37 \\
\hline $\mathrm{Nb}$ of acq of assets $(\mathrm{t}+366)$ & 0.4314 & 0 & 0.3962 & 0 & 0.6076 & 0 & 1.21 & 0.35 \\
\hline QTOBIN (-1) & 1.5017 & 1.0669 & 1.4588 & 1.1221 & 1.8842 & 1.1952 & 1.21 & 0.24 \\
\hline QTOBIN (0) & 1.3725 & 1.0107 & 0.936 & 0.9202 & 1.7773 & 1.0926 & $1.82 *$ & $2.78^{* * *}$ \\
\hline QTOBIN (1) & 1.1393 & 0.9463 & 1.0673 & 0.9516 & 1.0899 & 0.8624 & 0.14 & -1.42 \\
\hline $\mathrm{M} / \mathrm{B}(-1)$ & 2.0478 & 1.6688 & 2.0662 & 1.8085 & 2.2582 & 1.6693 & 0.78 & 0.7 \\
\hline $\mathrm{M} / \mathrm{B}(0)$ & 1.9805 & 1.6492 & 1.6561 & 1.3838 & 2.3 & 1.9553 & $2.75 * * *$ & $2.97 * * *$ \\
\hline $\mathrm{M} / \mathrm{B}(1)$ & 1.954 & 1.7207 & 1.6603 & 1.718 & 1.7347 & 1.5582 & 0.38 & 0.03 \\
\hline ROA (-1) & 0.003 & 0.0369 & -0.0049 & 0.038 & 0.0042 & 0.028 & 0.34 & -0.4 \\
\hline ROA (0) & -0.0237 & 0.0284 & -0.0725 & 0.0188 & -0.0059 & 0.0288 & $2.17 * *$ & $1.65^{*}$ \\
\hline ROA (1) & -0.039 & 0.0214 & -0.0178 & 0.0207 & -0.0639 & 0.0216 & -1.26 & -0.48 \\
\hline
\end{tabular}

In table 6, we examine variables related to bidder-specific and market-specific characteristics, in each of the individual hot and cold markets to try to uncover a characteristic set among firm and transaction characteristics that can be reliably associated with each type of merger market.

Results show that the percentage of shares acquired and the number of acquisitions announced in the years prior and following the announcement are significantly higher in hot markets. This is evidence that the hot periods are seen as favourable to larger investments programs.

Concerning the variables controlling for the financial strength of the bidding firm, Tobin's Q and ROA in the pre-announcement year prove that acquirers are not significantly overvalued and do not register better financial performances. However, these factors become significantly higher during the year of the announcement, a phenomenon that reverses in the post-announcement year (Note 17).

Since the Tobin's Q does not only control for overvaluation, we calculate the market-to-book equity ratio (M/B), for additional robustness. Our results on this ratio confirm the previous conclusion (Note 18).

The choice of making an acquisition at a time when overvaluation and the financial performance, are at their highest, is a strong evidence in favour of the merger timing and is consistent with the theory proposed by SV (2003) suggesting that during hot cycles, the financial market proves to be inefficient and some firms are valued incorrectly. Their model predicts that mergers are conducted by rational managers operating in less rational markets (inefficient).

Even if our results are consisting with SV (2003), we cannot reject, to this point, Roll's (1986) hubris hypothesis, which proposes that managers are irrational while the market is not, since in this case, we should also observe high performance prior to a merger and a reversion after.

Tests on the percentage of stock used in payment show highly significant t-test and z-test, which indicate a more intensive use of stock in hot markets. This evidence confirm Martin (1996) and Rau and Vermaelen (1998) findings that glamour bidders (firms with high market-to-book ratio) pay more frequently with stock than do value bidders (firms with low market-to-book ratio). Judging by the statistical tests, we can add new evidence that the bidders' managers are aware of the overvaluation of their firms and act rationally by timing their 
mergers and paying with stock (Note 19). This new evidence allows rejecting the hubris hypothesis with more confidence.

4.4.2 Multivariate Analysis of the Determinants of Bidders Performance for the Full Sample and during the Hot and Cold Merger Markets

To investigate the possible determinants of bidders performance in our windows of study, we conduct a multivariate cross-sectional analysis designed to explain the cumulative abnormal returns around the announcement of an acquisition and in the post-merger year, across the full sample, the hot and cold markets. The regressions include as independent variables all the variables introduced in the beginning of this section, with the exception of the variable percentage of stock that we replace by a dichotomous variable that takes 0 if the percentage of stock is comprised between 0 and 50 , and 1 if it is over $50 \%$.

We add the variable relatedness that we define as a dichotomous variable that controls for the relatedness of the target and acquirer activities. Relatedness takes the value 1 if the firms have 3-digit sic code in common and 0 otherwise. Target public status takes the value of 1 if the target is private or subsidiary and 0 if it is public. Hot is a dichotomous variable that equals 1 if the merger announcement takes place in a hot market and 0 otherwise. Cold is a dichotomous variable that equals 1 if the merger announcement takes place in a cold market and 0 otherwise.

Table 7. Determinants of abnormal returns for the hot and cold acquisition markets and for the full sample

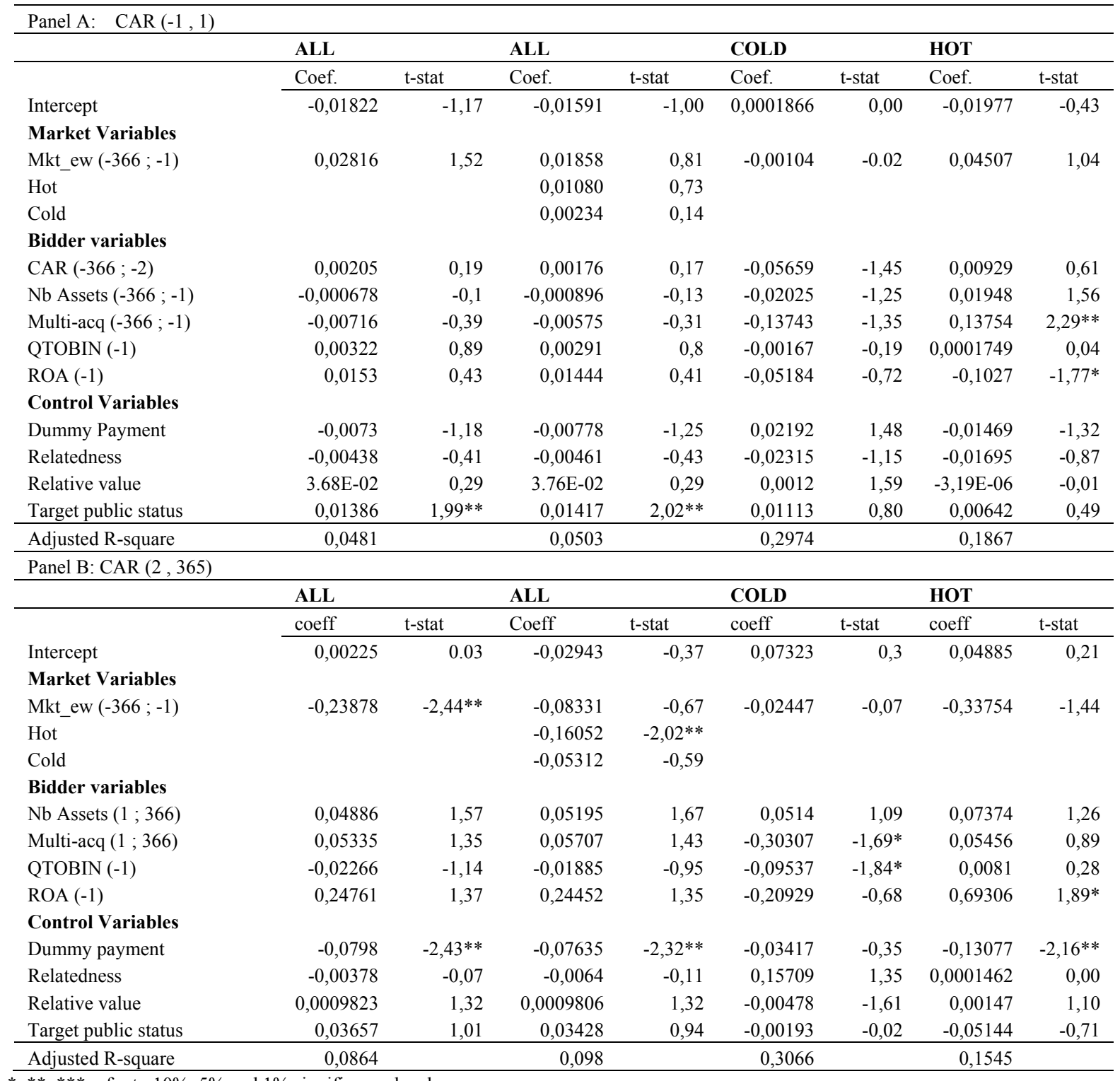

$*, * *, * * *$ refer to $10 \%, 5 \%$ and $1 \%$ significance levels. 
Panel A of table 7 shows that a negative coefficient is associated with the use of stock in hot markets. This is consistent with Myers and Majluf (1984) factors, but surprisingly, this factor is not significant, in all markets, which suggests that during the announcement of a merger the means of payment is not necessarily the most important factor that allows valuing the merger. Moreover, a positive coefficient on the acquisitions of private and subsidiaries is consistent with the literature (Fuller et al. (2002), Bradley and Sundaram (2006)). In fact, this positive coefficient on non-public targets can be explained the arguments suggesting that since there are greater information asymmetries between the buyer and the seller of a non-public target, the buyer will seek to obtain an adverse selection discount, in order to be compensated for information asymmetry.

Surprisingly, the Q-ratio which proxies for firm quality is not significant in all periods. Investors do not seem to place weight on this factor, even if it gives certification of the project quality and the management competence. However, more weight is placed on ROA in the hot markets. Investors seem to be more interested in the earnings realised by the bidder than in the whole quality of the firm. This result is consistent with the overoptimism in hot markets.

During the announcement window, the sign of the coefficient of the means of payment is consistent with the literature, although it is not significant in all markets. Panel B shows that, in the post-merger year, the coefficient on this variable becomes negative and significant for the full market and during hot markets, which proves that mergers where majority stock is used are worse, especially in the hot markets since the coefficient is higher.

The observation of the payment dummy in the post-merger year gives another evidence on the inability of the market to value the bidder and the transaction. Investors are overoptimistic during the acquisition announcement especially in hot cycles. However, the market is able to correct itself on a longer term.

Coefficient of hot dummy is negative and significant, while the coefficient of cold dummy is negative but not significantly different from zero. Consequently, the post-merger underperformance is higher in hot markets compared to other times.

\section{Conclusion}

Using a sample of 462 Canadian acquisitions between 1988 and 2002, we investigate the existence of timing process for mergers and acquisitions. To produce our results, we use the aggregate number of mergers to search for periods that are more favorable for mergers (i.e. to distinguish between hot and cold merger markets).

Our methodology consists of studying acquirer abnormal returns over three windows, pre-, post- and around the announcement of the acquisitions, in each market cycle (hot markets versus cold markets). Our results provide evidence that mergers are driven by stock market valuation and that these events occur during periods when investors are highly overoptimistic and react irrationally to a merger announcement. In fact, acquirers in hot markets register significantly higher abnormal performances than acquirers in cold markets; investors react better to the acquisitions announced during the hot markets even if the payment is made with stock. Our evidence suggests that short-run market perceptions may lead to takeover activity. This evidence is consistent with SV arguments.

The evidence that the stock returns reverse in the post-merger announcement year and the fact that the means of payment is a highly explanatory variable of the post-merger underperformance proves that the market can correct itself in the longer term.

Our results allow rejecting the synergy hypothesis and the economy-wide shocks, since these hypotheses do not predict the performance reversion that we observe.

We also find evidence that bidders' managers are aware of the overvaluation of their firms and act rationally by timing their mergers and paying with stock, since they choose to announce their acquisition when the overvaluation is at its highest. This evidence allows rejecting the hubris hypothesis.

However, if the investors have unrealistic expectations about the synergies from a merger, managers would not make these acquisitions unless they have personal motivations. This suggests that managerial motivations are associated to investors' sentiment to explain better the timing of mergers and acquisitions.

\section{Acknowledgements}

I would like to thank Edith Ginglinger, Meziane Lasfer, Jochen Lowrenz, Alain Chevalier and seminar participants at the 2005 European Financial Association meeting, the 2005 French Finance Association meeting, the $3^{\text {rd }}$ International Finance Conference and 2006 European Financial Management Symposium on Behavioral Finance, St Olaf University, 2008, Hamline School of Business Research Workshop, 2011 for helpful discussions and comments. 


\section{References}

Andrade G., Mitchell, M., \& Stafford, E. (2001). New evidence and perspectives on mergers. Journal of Economic Perspectives, 15, 103-120. http://dx.doi.org/10.1257/jep.15.2.103

Ang J. S., \& Cheng Y. (2006). Direct Evidence on the Market Driven Acquisition Theory. Journal of Financial Research, 29(2), 199-216. http://dx.doi.org/10.1111/j.1475-6803.2006.00174.x

Bayless M., \& Chaplinsky S. (1996). Is There a Window of Opportunity for Seasoned Equity Issuance? Journal of Finance, 51, 253-278.

Bhagat S., Shleifer, A., \& Vishny, R. (1990). Hostile takeovers in the 1980s: the return to corporate specialization,. Brookings Papers on Economic Activity: Microeconomics, 1-72. http://dx.doi.org/10.2307/2534780

Blair M. (1993). The deal decade: what takeovers and leveraged buyouts mean for Corporate governance, Brookings Institution, Washington.

Bradley M., \& Sundaram A. (2006). Do acquisitions drive performance or does performance drive acquisitions? A Re-Assessment of the Evidence, Working paper, Duke University.

Choe H., Masulis R., \& Nanda V. (1993). Common stock offerings across the business cycle. Journal of Empirical Finance, 1, 3-31. http://dx.doi.org/10.1016/0927-5398(93)90003-A

Directory of Mergers \& Acquisitions in Canada, Annual Edition. (1988-2002). Crosbie \& Co. http://crosbieco.com

Dong M., Hirshleifer D., Richardson S., \& Teoh S. H. (2006). Does investor misvaluation drive the takeover market? Journal of Finance, 61(2), 725-762. http://dx.doi.org/10.1111/j.1540-6261.2006.00853.x

Eckbo E. (1986). Mergers and the Market for Corporate Control: The Canadian Evidence. Canadian Journal of Economics, 19, 236-260. http://dx.doi.org/10.2307/135282

Foerster S. R., \& Karolyi G. A. (1999). The Effects of Market Segmentation and Illiquidity on Asset Prices: Evidence from Foreign Stocks Listing in the US. Journal of Finance, 54, 981-1014. http://dx.doi.org/10.1111/0022-1082.00134

Friedman J. (2006). Stock Market Driven Acquisitions: Theory and Evidence, Harvard Working Paper.

Fuller K., Netter J., \& Stegemoller M. (2002). What Do Returns to Bidding firms Tell Us? Evidence from Firms That Make Many Acquisitions. Journal of Finance, 57, 1763-93. http://dx.doi.org/10.1111/1540-6261.00477

Gorton G., Kahl M., \& Rosen R. (2009). Eat or be eaten: A theory of mergers and merger waves. Journal of Finance, 64(3), 1291-1344. http://dx.doi.org/10.1111/j.1540-6261.2009.01465.x

Graham J., \& Harvey C. (2001). The theory and practice of corporate finance: evidence from the field. Journal of Financial Economics, 60, 187-243. http://dx.doi.org/10.1016/S0304-405X(01)00044-7

Gugler K., Mueller D., \& Yurtoglu B. (2006). The determinants of merger waves, WZB - Markets and Politics Working Paper No. SP II 2006-01.

Hickman, W. B. (1953). The Volume of Corporate Bond Financing, National Bureau of Economic Research, New York.

Holmstrom B., \& Kaplan S. N. (2001). Corporate governance and merger activity in the united states: Making sense of the 1980s and 1990s. Journal of Economic Perspectives, 15, 121-144. http://dx.doi.org/10.1257/jep.15.2.121

Jensen M. (1986). Agency costs of free cash flow, corporate finance, and takeovers. American Economic Review, $76,323-329$.

Jensen M. (1988). Takeovers: Their Causes and Consequences. Journal of Economic Perspectives, 2(1), 21-48.

Jensen M. (2004). The agency costs of overvalued equity and the current state of corporate finance. European Financial Management, 10, 549-565. http://dx.doi.org/10.1111/j.1354-7798.2004.00265.x

Lambrecht B. M. (2004). The Timing and Terms of Mergers Motivated by Economies of Scale. Journal of Financial Economics, 72(1), 41-62. http://dx.doi.org/10.1016/j.jfineco.2003.09.002

Loughran T., Ritter J. R., \& Kristian Ryndqvist. (1994). Initial Public Offerings: International Insights. Pacific Basin Finance Journal, 2, 165-199. http://dx.doi.org/10.1016/0927-538X(94)90016-7 
Martin K. (1996). The method of payment in corporate acquisitions, investment opportunities, and managerial ownership. Journal of Finance, 51, 1227-1246.

Meeks G. (1977). Disappointing marriage: a study of the gains of the merger, University of Cambridge Occasional Paper 51, Cambridge University Press, Cambridge.

Mergerstat Review. http://www.mergerstat.com.

Mitchell M. L., \& Mulherin J. H. (1996). The impact of industry shocks on takeover and restructuring activity. Journal of Financial Economics, 41, 193-229. http://dx.doi.org/10.1016/0304-405X(95)00860-H

Morck R., Shleifer A., \& Vishny R. (1990). Do Managerial Objectives Drive Bad Acquisitions? Journal of Finance, 45, 31-48.

Myers S. C., \& Majluf N. S. (1984). Corporate Financing and Investment Decisions When Firms Have Information That Investors Do Not Have. Journal of Financial Economics, 13, 187-221. http://dx.doi.org/10.1016/0304-405X(84)90023-0

Nelson R. L. (1959). Merger Movements in American Industry. Princeton University Press: Princeton, N.J.

Rau P. R., \& Vermaelen T. (1998). Glamour, value and the post-acquisition performance of bidding firms. Journal of Financial Economics, 49, 223-253. http://dx.doi.org/10.1016/S0304-405X(98)00023-3

Rhodes-Kropf M., \& Viswanathan S. (2004). Market valuation and merger waves. Journal of Finance, 59, 2685-2718. http://dx.doi.org/10.1111/j.1540-6261.2004.00713.x

Rhodes-Kropf M., Robinson D. T., \& Vishanathan S. (2005). Valuation Waves and Merger Activity, The Empirical Evidence. Journal of Financial Economics, 77, 561-603. http://dx.doi.org/10.1016/j.jfineco.2004.06.015

Roll R. (1986). The Hubris Hypothesis of Corporate Takeovers. Journal of Business, 59, 197-216. http://dx.doi.org/10.1086/296325

Rumelt R. (1974). Strategy, structure, and economic performance (Harvard Business School Press: Boston).

Servaes H. (1991). Tobin's Q and the Gains from Takeovers. Journal of Finance, 46, 409-419.

Shleifer A., \& Vishny R. W. (2003). Stock Market Driven Acquisitions. Journal of Financial Economics, 70, 295-311. http://dx.doi.org/10.1016/S0304-405X(03)00211-3

Steiner P. (1975). Mergers: motives, effects, policies. University of Michigan Press: Ann Arbor.

Sudarsanam S. (2003). Creating Value from Mergers and Acquisitions: The Challenges. FT, Prentice Hall.

Thomson Financial. (2002-2005). News Releases. http://www.thomson.com/financial/financial.jsp

\section{Notes}

Note 1. Rau and Vermaelen (1998) find that the long-run underperformance of acquirers is driven by the post-acquisition performance of low book-to-market acquirers. These acquirers earn superior returns around the announcement, however, their long-run performance is worse than the high book-to-market acquirers. Loughran and Vijh (1997) also suggest that the long-run underperformance of stock acquisitions reflects the overvaluation of the acquirers around the acquisition announcement.

Note 2 Based on figures from Crosbie \& Co., Directory of Mergers \& Acquisitions in Canada.

Note 3. Based on figures from Mergerstat Review.

Note 4. Hot markets are defined by Bayless and Chaplinsky (1996) as periods of high equity volume. They argue that the decision to issue equity is linked with the costs of issue. They define hot and cold issue markets based on aggregate issue equity volume. The authors provide evidence that windows of opportunity exist when otherwise identical firms receive favorable prices for new seasoned equity. They find that the average price reaction in hot markets is significantly less negative while the price reaction in cold markets is significantly more negative than at other times.

Note 5. Loughran and Ritter (1995) suggest that high returns on SEOs are also due to investors' over-optimism.

Note 6. This procedure was used by Bayless and Chaplinsky (1996), who define hot and cold issue markets based on the aggregate equity issue volume.

Note 7. Foerster and Karolyi (1999) study non-US firms cross-listing shares on U.S. exchanges (American Depositary Receipts). They use a window of study of one year prior to listing and one year following the listing. 
Note 8. Fuller et al. (2002) among others.

Note 9. Our windows are based on calendar days, not on stock market trading days.

Note 10. Results of the tests conducted in the remaining paper are robust to the use of the capital asset pricing model and to the use of the equal-weighted and value-weighted market indexes.

Note 11. We report only results obtained with the market model and the equal weighted market index.

Note 12. To investigate the consistency of these results over time, we reconduct the same tests for each of the 2 hot and 3 cold markets reported in figure 1 and table 2 individually. The abnormal returns levels and movements reported in table 3 are confirmed for each individual hot and cold market. This evidence suggests that the overall results are not driven by on any one period.

Note 13. Our results hold for any cut-off between $50 \%$ and $70 \%$ stock paid in the transaction since most observations are concentrated either between 0 and $30 \%$ or between $60 \%$ and up.

Note 14. Results hold for any cut-off in the proportion of stock used in payment, between $50 \%$ and $70 \%$ of the total amount of the transaction.

Note 15 . Results hold for any cut-off in the proportion of stock used in payment, between $50 \%$ and $70 \%$ of the total amount of the transaction.

Note 16.We also control for the TSX value-weighted index.

Note 17. T-tests and z-tests conducted on the difference between Qtobin (0) and Qtobin(-1) (not reported in table $5)$ are consecutively -0.44 and -0.51 . The same tests conducted on the difference between Qtobin ( 0$)$ and Qtobin(1) are consecutively 2.33 (significant at the 5\% level) and 3.55 (significant at the $1 \%$ level)

Note 18. T-tests and z-tests conducted on the difference between M/B (0) and M/B (-1) (not reported in table 5) are consecutively -0.21 and -0.42 . The same tests conducted on the difference between Qtobin ( 0$)$ and Qtobin(1) are consecutively 3.19 and 2.61 (both significant at the $1 \%$ level)

Note 19. To explore the managerial motivations and control for the idea that they earn private benefits from the transactions, we aim to conduct tests on the acquiring managers' compensation structure and the movements of their compensation before and following the acquisition announcement. The tests are inconclusive since data are available for less $10 \%$ of the sample. 


\section{Appendix: Summary of variables}

This table describes the variables used in our analysis.

\begin{tabular}{|c|c|}
\hline \multicolumn{2}{|c|}{ Market related variables } \\
\hline Mkt_ew & cumulative returns on the TSE equal-weighted index in the 366 days prior to the announcement (t-366). \\
\hline Hot & $\begin{array}{l}\text { a dichotomous variable that equals } 1 \text { if the merger announcement takes place in a hot market and } 0 \\
\text { otherwise. }\end{array}$ \\
\hline Cold & $\begin{array}{l}\text { dichotomous variable that equals } 1 \text { if the merger announcement takes place in a cold market and } 0 \\
\text { otherwise. }\end{array}$ \\
\hline \multicolumn{2}{|c|}{ Bidder related variables } \\
\hline CAR & $\begin{array}{l}\text { cumulative announcement abnormal return on windows of respectively }(-1,1) ;(-366,-2) ;(2,366) \text { days } \\
\text { around the announcement (day } 0) \text {. The abnormal returns are computed for day } t \text {, as the return on stock } \mathrm{i} \\
\text { minus the return on the market. }\end{array}$ \\
\hline Multi-acq. & $\begin{array}{l}\text { number of mergers and acquisitions of majority interest made by the same acquirer in the year preceding } \\
\text { the announcement ( } t-366) \text { or following the announcement }(t+366) \text {. }\end{array}$ \\
\hline $\mathrm{Nb}$. of acq. of assets & $\begin{array}{l}\text { number of acquisition of assets made by the same acquirer in the years preceding and following the } \\
\text { announcement }((\mathrm{t}-366) \text { and }(\mathrm{t}+366)) \text {. }\end{array}$ \\
\hline QTobin & $\begin{array}{l}\text { sum of market value of equity, book value of debt and preferred stock by total assets measured at the end of } \\
\text { the year of the merger announcement (0), the end of the year prior to the announcement (-1) and the end of } \\
\text { the year following the announcement (1). }\end{array}$ \\
\hline $\mathrm{M} / \mathrm{B}$ & $\begin{array}{l}\text { market-to-book equity ratio measured at the end of the year of the merger announcement (0), the end of the } \\
\text { year prior to the announcement (-1) and the end of the year following the announcement (1). }\end{array}$ \\
\hline ROA & $\begin{array}{l}\text { ratio of the return on assets measured at the end of the year of the merger announcement }(0) \text {, the end of the } \\
\text { year prior to the announcement (-1) and the end of the year following the announcement (1). }\end{array}$ \\
\hline \multicolumn{2}{|c|}{ Transaction related variables } \\
\hline Shares acquired & percentage of target shares acquired in the transaction. \\
\hline Relative value & $\begin{array}{l}\text { ratio of target-to-bidder size. We use the ratio of total market equity of the target to the total market equity } \\
\text { of the acquirer. Wherever it is not available we use the ratio of total assets instead. }\end{array}$ \\
\hline$\%$ Stock & percentage of stock used in the transaction payment. \\
\hline Dummy Payment & dichotomous variable that takes 1 if the payment is done with more than $50 \%$ stock. \\
\hline Relatedness & $\begin{array}{l}\text { dichotomous variable, which controls for the relatedness of the target and acquirer activities. Relatedness } \\
\text { equals } 1 \text { if the firms have } 3 \text {-digit sic code in common et takes } 0 \text { otherwise. }\end{array}$ \\
\hline \multicolumn{2}{|l|}{ Target related variab } \\
\hline Target public status & tomous variable that equals 1 if the target is public and 0 otherwise. \\
\hline
\end{tabular}

